\title{
Profil nátrubkového nástroje z pohledu organologické systematiky založené na akustických vlastnostech
}

\section{The Horn of Brass Instruments from the Organological Point of View Based on Music Acoustic}

\author{
Viktor Hruška / hruska.viktor@hamu.cz \\ Musical Acoustic Research Center, Music and Dance Faculty, Academy of Performing Arts, \\ Praha, CZ
}

\begin{abstract}
The text presents the key topics from advanced organology of brass instruments (labrosones) based on their acoustic features. It reaches from the basics (natural tones of cylindrical and conical tubes) through the intermediate level of description (Bessel waveguides, input impedance, elements of nonlinear harmonic distorsion) to the definition of brassiness potential and the systematics of labrosones based on it. Possibilities of practical measurements and corresponding simple formulas are presented.
\end{abstract}

\section{Keywords}

organology, music acoustics, brass intruments, labrosones, brassiness potential 
Během zpracovávání akustické dokumentace $\mathrm{k}$ připravované monografii o Josefu Šedivovi a jeho nástrojích jsem několikrát narazil na fakt, že v české literatuře neexistuje text na pomezí hudební akustiky a organologie, který by v dostupné formě obsahoval témata týkající se akustiky nátrubkových nástrojů. Vzhledem k tomu, že toto téma je potenciálně velmi široké, omezí se následující odstavce jen na jeden klíčový výsek: hudebně významné vlastnosti trubic aerofonů, zejména vzhledem k jejich profilu. Velké množství charakteristických vlastností (chromatizace, postup výroby, technika hry aj.) je geometrií přímo podmíněno a navíc je jistá část těchto teorií společná jak nátrubkovým nástrojům se strojivem, tak aerofonům s tónovými otvory.

Nástrojovou skupinou, o kterou v následujících odstavcích půjde zejména, jsou tedy nástroje rozeznívané proudem vzduchu přerušovaným kmitajícími hráčovými rty, někdy souhrnně označované jako labrosony. Ekvivalentní označení nátrubkové nástroje by muselo implicitně zahrnovat i příslušné nástroje bez nátrubku (např. mušle a zvířecí rohy), označení žestové nebo plechové se pro změnu nevhodně opírá o materiál, který se může měnit i při zachování stejného akusticko-organologického základu (např. cink a klapková trubka). ${ }^{1}$ Na několika místech textu bude z ilustrativních důvodů přibrán klarinet a hoboj jako známí zástupci limitních případů válcového a kuželového nástroje. V zásadě však tato studie nemá ambici řešit speciální otázky nástrojů s tónovými otvory.

Text se bude snažit vystavět téma od základu, minimálně z rozsahových důvodů jsou ovšem u čtenáře předpokládány základní znalosti hudební akustiky.

Místo delšího úvodu bude vhodné uvést motivační problém, na který text odpovídá. Srovnejme například baryton a Kaiserbariton Václava Františka Červeného nebo nástroj stejné výšky a ladění s označením Herkulesofon z dílny Josefa Šedivy. ${ }^{2}$ Všechny zmíněné patří mezi chromatické kónické nátrubkové nástroje ovládané většinou ventilovým strojivem. Sachsova-Hornbostelova systematika ${ }^{3}$ je tedy už dále nerozlišuje. Jakým způsobem je při rozdílném profilu trubic možné zachovat stejné ladění a stejné rozložení alikvótních tónů? Existuje způsob jak na základě profilu trubice zavést organologickou systematiku těchto nástrojů? Na tyto otázky budou odpovídat následující odstavce.

Před vlastním textem je namístě stručně shrnout současný stav literatury, která se zájemci o toto téma nabízí. Z rozsahových důvodů zůstaneme u české literatury, následující text se o některé významné zahraniční autority opírá. Nejpokročilejší je ve svém popisu akustika Václava Syrového. ${ }^{4}$ Tato kniha má z pochopitelných důvodů spíše kompendiální než výkladový charakter a jako základní literatura je bez doprovodného komentáře

1 V naší literatuře podobnou diskuzi publikovali Jaroslav Ušák (obecnější pojem nástroje nátrubné pro instrumenty rozeznívané kmitajícími rty nezávisle na př́ítomnosti nátrubku) a Jan Rychlík. (UŠÁK, Jaroslav. Pokus o nové roztřídění hudebních nástrojů. Hudebni rozhledy. 1927, (2), s. 70. RYCHLÍK, Jan. Žestové nástroje bez strojiva. Praha: SNKLHU, 1960, s. 7-8.)

2 Viz publikaci ŽŮRKOVÁ, T. a HRUŠKA, V. Josef Šediva a jeho sbírka hudebních nástrojů v Národním muzeu - Českém muzeu hudby. Praha: Národní muzeum, 2016. Editio Monographica Musei Nationalis Pragae. ISBN 978-80-7036-505-2.

3 HORNBOSTEL, Erich Moritz von a SACHS, Curt. Systematik der Musikinstrumente: Ein Versuch. Zeitschrift für Ethnologie. 1914, (4-5), s. 553-590.

4 SYROVÝ, V. Hudebni akustika, s. 240nn. 
na mnoha místech jen těžko stravitelná. Antonín Špelda ${ }^{5}$ šetří s vyjadřováním informací fyzikálními vzorci a zůstává jen u velmi jednoduchého pohledu. Stručný, zjednodušený přehled podává rovněž příslušná kapitola Vratislava Vimra z kolektivního skripta Stavba hudebnich nástrojů. ${ }^{6}$ Vědecký přínos tohoto textu je přirozeně velmi malý. Informace $\mathrm{v}$ něm obsažené jsou předloženy $\mathrm{k}$ uvěření v mnoha př́ípadech bez argumentace a nepřekračují úroveň nutnou k nejzákladnější orientaci. Pavel Kurfürst se ve své Organologii tomuto tématu nevěnuje. Také akustická kapitolka v Rychlíkových Žestových nástrojích bez strojiva je velmi stručná a nezachází za rozsah Špeldovy akustiky, na kterou se odvolává.

Nakonec jen krátkou názvoslovnou poznámku. V následujícím textu se úplné pojmenování vyšši harmonická frekvence, frekvence v harmonickém poměru atp. stahuje, jak je běžné, na tvar harmonická.

\section{Přirozené tóny}

Jakákoli fyzikální disciplína, velkou část hudební akustiky nevyjímaje, je vždy nauka pracující s modely reálného světa. Tyto modely mohou vystupovat v různých úrovních idealizace nebo zjednodušení a největším uměním je právě volit mezi náročností a nepřiměřeným zanedbáváním. Toto rozhodování bude červenou nití následujících odstavců.

Akustický popis dělí hudební nástroj na tři základní části označované jako excitátor, oscilátor a rezonátor. Trubice aerofonu je z hlediska tohoto rozdělení rezonátor, tedy prvek, který díky své schopnosti akumulovat energii na určitých frekvencích zesiluje a filtruje zvuk vzniklý na oscilátoru. U většiny dechových nástrojů navíc platí, že rezonanční vlastnosti trubice jsou natolik výrazné, že dovolují oscilátoru operovat jen na určitých tónech. ${ }^{8}$ Naším prvním cílem bude zjistit frekvence těchto přirozených tónů a jejich souvislost $\mathrm{s}$ tvarem nástroje.

Nejčastější a poměrně dobře splnitelné přiblížení spočívá v uvažování trubice jako objektu s jednou dimenzí natolik převažující, že je možné ho považovat za jednorozměrný. Tento model má samozřejmě své meze: pro krátké vlnové délky (vysoké frekvence) už široké části nástroje musí mít trojrozměrný popis. Tyto velmi vysoké frekvence se však nenalézají v hratelném rozsahu. Mají vliv na tvar spektra, ${ }^{9}$ ale jako fundamentály nevystupují.

$\mathrm{V}$ podstatě jediný případ, ve kterém jsou přrislušné akustické rovnice přehledně a bez

5 ŠPELDA, A. Hudebni akustika, s. 194nn.

6 VIMR, V. Část D: Plechové hudební nástroje a nástroje bicí. In Stavba hudebních nástrojů. s. 102nn.

$7 \quad$ KURFÜRST, P. Organologie, s. 251nn.

8 Výjimku tvoří např́ílad „aerofon“ lidský hlas. Hlasivky mohou kmitat na rezonanční frekvenci vokálního traktu, ale také - a to v praxi nejčastěji - mimo ni. Přesněji, klíčový je poměr vstupní impedance nástroje $\mathrm{k}$ impedanci hráčova vokálního traktu (viz dále).

9 Jedná se o vlnové délky, které v nástroji neexistují „podél“ (míněno např. mezi nátrubkem a roztrubem), ale „např́ič“ (např. mezi stěnami širokých trubic). Při překročení vysoké hraniční frekvence pak takových „prríčných“, neharmonicky uspořádaných vlnových délek začne existovat velké množství. Zde je úzká souvislost s mezí, za kterou už spektrum zvuku nástroje mění svůj charakter z převážně čárového na šumové. Pozor, jedná se pouze o geometrické umístění vlnové délky. Charakter vlnění je pochopitelně stále podélný. 
zanedbání řešitelné, je úzká trubice neproměnného průřezu, nejběžněji válcová, s dokonale otevřenými konci nebo jedním koncem dokonale uzavřeným. Stojaté vlnění se může vytvářet pouze tak, aby na otevřeném konci měl akustický tlak uzel a na uzavřeném kmitnu. Pro tyto případy dostáváme známé výsledky v podobě celistvých násobků polovin vlnových délek a tedy řady harmonicky uspořádaných frekvencí (tzn. v poměru $1: 2: 3$ : $4: 5$...) pro oba konce otevřené a lichých násobků čtvrtin vlnových délek a tedy řady „lichých“ frekvencí pro trubici na jednom konci uzavřenou (1:3:5:7 ...).

Všeobecně asi nejznámějšími důsledky řečeného je charakteristický zvuk „lichých“ spekter krytých varhanních píštal a šalmajového rejstř́ku klarinetu, u druhého jmenovaného navíc neschopnost přefukovat do oktávy $(1: 2)$, ale až do duodecimy (1:3).

$\mathrm{V}$ této části budeme nadále vždy předpokládat, že trubice je na jednom konci dokonale uzavřená hráčovými rty nebo třtinovým (dvoj-)plátkem a na druhém dokonale otevřená.

Už další z běžných přiblížení, trubice kuželového profilu, takto jednoduché řešení nemá. Běžně se uvádí, že kuželová trubice má vlastní frekvence přibližně harmonicky uspořádány (tzn. „má všechny přefuky“). Takové chování je ovšem podmíněno vhodnou geometrií. Přŕsně vzato je i trubice klarinetu bez ozvučníku kónická. Od vyústění hubičky k vstupu ozvučníku se však plocha jejího průřezu nezmění ani dvojnásobně, zatímco hoboj na přibližně stejné délce změní obsah plochy příčného řezu o dva řády.

Otázka tedy zní, jaká trubice je „dostatečně kuželovitá“. K představě dobře poslouží jednoduchá geometrická kontrukce (viz Obr. 1). Všechny kuželové trubice mají tvar pláště komolého kužele (tzn. „s odříznutou špičkou“). Měrou „dostatečné kuželovitosti“ je pak poměr délek myšleného doplňku komolého kužele do špičky a reálné kuželové trubice. Jen pokud je tento poměr velmi malý, dá se trubice považovat za kuželovou ve smyslu organologické systematiky. Opět pro ilustraci, kuželový doplněk je vzhledem k reálné délce nástroje u hoboje malý, myšlený doplněk klarinetu ovšem reálnou délku trubice zhruba dvojnásobně překročí.

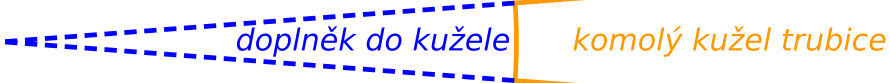

Obr. 1 Pomocná konstrukce k ilustraci vlastností kuželového vlnovodu. Z akustického hlediska je $v$ tomto př́padě doplněk př́liš velký na to, aby byly frekvence harmonicky uspořádány.

Vlastní frekvence trubice jsou tedy harmonicky uspořádané jen u zcela teoretického případu kužele bodově buzeného ve své špičce. Reálně je možné postavit kuželovou trubici o v podstatě libovolném intervalu prvního přefuku (mezi oktávou a duodecimou). S ohledem na kvalitu tónu, celkovou ovladatelnost a snadnost tvorby tónu (viz dále) je ovšem potřeba co nejvíce se blížit harmonickému uspořádání vlastních frekvencí, at už dokonalému (hoboj, kuželový doplněk velmi malý) nebo „lichému“ $1: 3: 5:$ :.. 
(klarinet, kuželový doplněk velmi velký). Vlivem odchylky od ideálního kužele („s nulovým doplňkem“) bývají nicméně vlastní frekvence rozloženy mírně neharmonicky (viz tabulku dále).

Těžištěm této studie ovšem mají být retné aerofony, u kterých se přísně válcové nebo dokonale kuželové profily nevyskytují, snad až na výjimky didgeridoo a alpského rohu. Obecně profily těchto nástrojů žádné široce známé křivce neodpovídají. Relativně blízko jsou jim zobecněné hyperboly a jim odpovídající tvary trubic nazývané Besselovy ${ }^{10}$ vlnovody.

Pro srovnání zatím zmíněných případů následuje tabulka s hodnotami vlastních frekvencí a odpovídajících tónových označení. Všechny trubice mají délku $1300 \mathrm{~mm}$, tedy orientačně stejnou jako B trubka. Povšimněme si zejména velmi nevýhodného rozložení vlastních frekvencí u kuželového vlnovodu s větším doplňkem.

Obr. 2 Srovnání profilů různých trubic. Válcová (nahoře), dvě různé kuželové (uprostřed) a Besselův vinovod podobný kónickému typu reálných profilů.

\begin{tabular}{|c|c|c|c|c|c|c|c|c|c|c|c|}
\hline \multicolumn{3}{|c|}{ Válec } & \multicolumn{3}{|c|}{ Kužel s větším doplňkem } & \multicolumn{3}{|c|}{$\begin{array}{c}\text { Kužel s menším } \\
\text { doplňkem }\end{array}$} & \multicolumn{3}{|c|}{ Besselův vlnovod $(y=1)$} \\
\hline$f[\mathrm{~Hz}]$ & $\begin{array}{l}\text { pomér } \\
k f_{0}\end{array}$ & tón & $f[\mathrm{~Hz}]$ & $\begin{array}{l}\text { pomèr } \\
k f_{0}\end{array}$ & tón & $f[\mathrm{~Hz}]$ & $\begin{array}{l}\text { pomèr } \\
k f_{0}\end{array}$ & tón & $f[\mathrm{~Hz}]$ & $\begin{array}{c}\text { pomér } \\
\mathrm{k} f_{0}\end{array}$ & tón \\
\hline 65 & 1 & C, -11 & 102 & 1 & Gis, -24 & 121 & 1 & $H_{1}-36$ & 123 & 1 & $\mathrm{H}_{1}-9$ \\
\hline 196 & 3 & $g, 0$ & 219 & 2,1 & $a_{1}-5$ & 243 & 2 & $h,-26$ & 246 & 2 & $h,-4$ \\
\hline 327 & 5 & $\mathrm{e}^{1},+14$ & 345 & 3,4 & $f^{1},-22$ & 368 & 3 & fis $^{1},-12$ & 370 & 3 & fis $^{1},-1$ \\
\hline 458 & 7 & $b^{1},-31$ & 473 & 4,6 & $b^{1},+27$ & 494 & 4,1 & $\mathrm{~h}^{1},-1$ & 493 & 4 & $h^{1},-2$ \\
\hline 588 & 9 & $d^{2},+2$ & 604 & 5,9 & $d^{2},+47$ & 621 & 5,1 & $\operatorname{dis}^{2},-3$ & 617 & 5 & $\operatorname{dis}^{2},-15$ \\
\hline 719 & 11 & $\begin{array}{l}\text { fis }^{2} \\
-50\end{array}$ & 734 & 7,2 & $\mathrm{fis}^{2},-13$ & 750 & 6,2 & $\begin{array}{l}\text { fis }^{2} \\
+23\end{array}$ & 740 & 6 & $\mathrm{fis}^{2},+1$ \\
\hline 850 & 13 & $\begin{array}{l}\text { gis }^{2} \\
+40\end{array}$ & 866 & 8,5 & $a^{2},-28$ & 879 & 7,3 & $a^{2},-1$ & 864 & 7 & $a^{2},-32$ \\
\hline 981 & 15 & $h^{2},-12$ & 997 & 9,8 & $h^{2},+17$ & 1010 & 8,3 & $h^{2},+38$ & 987 & 8 & $h^{2},+1$ \\
\hline
\end{tabular}

Tab. 1 Vlastní frekvence, jejich poměry a odpovídající tóny pro čtyři různé profily trubic. Besselův vinovod by stačilo mírně podladit a odpovídal by $B$ trubce prímo.

10 Friedrich Wilhelm Bessel (1784-1846) byl německý matematik a astronom s výraznými zásluhami v geometrii, geodézii a matematické analýze. Jeho jménem je označována rodina matematických funkcí, která - kromě mnoha jiných aplikací - odpovídá řešením rozložení tlaku a rychlosti ve speciálních případech rozšiřujících se trubic („besselových“ vlnovodech). 
Zatím nebyla zodpovězena otázka, proč stojaté vlnění vzniká právě na těchto frekvencích, které ve většině případů nejsou v celočíselných poměrech, a tedy neodpovídají klasické intuitivní představě analogie s flažolety. Kompletní fyzikální zdůvodnění patří už mezi relativně náročnější, takže se podržíme pouze základních důvodů a ilustrace. S rozšiřující se trubicí se rozšiřuje i vlnoplocha přenášené akustické vlny, s čímž souvisí lokální změna rychlosti zvuku. Dochází tak ke zvětšování vzdáleností mezi uzly směrem k otevřenému širokému konci trubice - místa se stejnou fází stojatého vlnění od sebe nejsou v trubici vždy stejně vzdálená. Pokud bychom chtěli analogii se strunou, pak změna průřezu trubice se kvalitativně chová obdobně jako změna tlouštky struny. Praktická zkušenost pak svědčí o tom, že například struna s vadným opletem nemá flažolety na „svých“ pozicích.

Alespoň krátce se musíme dotknout problému prodlužování trubice pomocí ventilového mechanismu nebo snižce. Snižcem lze teoreticky libovolně jemně korigovat ladění tónu, nevýhodou je ale menší obratnost v rychlejších stupnicových bězích apod. Z hlediska ovládání je sice ventilový mechanismus jednodušší, cena je ovšem zaplacena v nemožnosti naladit jednotlivé ventily a zároveň jejich potřebné kombinace čistě. Aritmetický součet délek ventilů je totiž nutně menší, než potřebné prodloužení. Např. krok o půl tónu odpovídá změně zhruba o $6 \%$, o tón asi o $12 \%$, ale malá tercie už vyžaduje změnu o $19 \%$. Odtud pochází nutnost používání čtvrtého a dalších ventilů nebo dolad'ovacích tahů.

\section{Vyzařování zvuku a parametr impedance}

Je zřejmé, že předpoklad trubice na jednom konci dokonale uzavřené a na druhém dokonale otevřené, není reálně splněn. Zdůvodnění je zcela prosté: dokonalé odrazy by znamenaly, že žádná akustická energie trubici nikdy neopustí a nástroje budou němé. Je tedy nutné postoupit na další úroveň popisu.

V akustice a teorii mechanického vlnění existuje celá rodina veličin nazývaných impedance. Etymologie z latinského impedire (bránit, překážet) se dobře hodí na původní význam v elektrických obvodech, kde impedance představuje komplexní odpor součástky. V akustice se zavádí jako poměr akustického tlaku k akustické rychlosti, kterou vyvolává. ${ }^{11}$ Impedance trubice nepřímo úměrně závisí na ploše jejího průřezu (tzn. čím větší průřez, tím menší impedance). Důležité je, že jakýkoli skok impedance má za následek částečný odraz akustického vlnění. Proto jsou také profily roztrubů a ozvučníků pokud možno co nejhladší. Ze stejného důvodu se negativně projevují na zvuku nástroje veškeré nepřesnosti v sesazení dílů, nedotáčení ventilů při otevírání a zavírání zápojek, deformace trubice promáčknutím apod.

Úplný odraz nastává, pokud nenulová impedance přímo sousedí s nulovou („dokonale volný prostor“) nebo nekonečně velkou („tuhá zed““). Intuitivně je zřejmé, že roztrub nebo ozvučník (a tím méně tónový otvor) nebudou představovat ostrý přechod do oblasti bez impedance. Stejně tak kmitající rty nebo plátek se dokonalému uzávěru pouze blíží.

Důsledkem nenulové impedance zakončení ozvučníku, roztrubu nebo tónového otvoru (tzv. vyzařovací impedance) je nedokonalý odraz vlnění a šíření zvuku z trubice.

11 Alternativně se používá místo tlaku budící síla a místo rychlosti objemová rychlost akustických částic. 
Vyzařovací impedance také zdánlivě mění délku nástroje. Kvůli ztrátám vyzařováním zní trubice o něco níže, než by jako dokonale otevřená měla. ${ }^{12}$ Zajímavým a dnes dobře zdokumentovaným důsledkem konečně velké impedance „uzavřeného“ konce plátkových nástrojů je možnost úpravou impedanční zátěže (tzn. nastavením dutiny ústní a vokálního traktu) dolad'ovat tóny během hry. ${ }^{13}$

Vlastnosti vyzařování nástroje velmi záleží na frekvenci zvuku. Pro každý poloměr otevřeného konce existuje tzv. mezní frekvence, na které se chování vyzařování mění. Odhad její hodnoty v herzech dostaneme, když číslo 108000 vydělíme průměrem ústí trubice v milimetrech. ${ }^{14}$ Nad touto frekvencí přestává roztrub představovat akustickou překážku a v podstatě všechen zvuk nástroj opouští. Znamená to ovšem, že na těchto frekvencích se jen ve velmi omezené míře tvoří stojaté vlnění - nedojde k dostatečnému odrazu zpět nástrojem - a rezonátor pozbývá svého zesilujícího efektu.

Impedance, které jsou vystaveny kmitající rty, se nazývá vstupní (input impedance). Nátrubkové nástroje hrají na frekvencích, které odpovídají maximům vstupní impedance. ${ }^{15}$

\section{Kvalita zvuku a nelineární jevy}

Velkou část podkladů k určení typických vlastností spektra a tedy do značné míry i barvy nátrubkových nástrojů máme už pohromadě. Retný tón (bzučení kmitajících rtů) pozůstává z řady harmonických se základní frekvencí jako nejsilnější a rovnoměrným poklesem zhruba $10 \mathrm{~dB}$ na oktávu. Rezonance kotlíku nátrubku naruší rovnoměrnost poklesu a do nástroje tak vstupuje signál s několika nízkými silnými harmonickými a propadem směrem k vyšším částem spektra. Z měření spekter uvnitř nástroje vyplývá, že před roztrubem jsou stále nejsilnější první harmonická a nejbližší vyššíi. ${ }^{16}$ Ty se ovšem velmi dobře odráží nástrojem zpátky (viz výše), takže kvůli efektivitě vyzařování bývá vně nástroje nejsilnější zpravidla až některá z dalších vyšších harmonických.

Typické spektrum v nižší a střední poloze má tedy tvar oblouku s vrcholem v okolí mezní frekvence roztrubu, za kterou intenzity opět klesají o 15 až $25 \mathrm{~dB}$ na oktávu. ${ }^{17}$ Na vyšších tónech nemusí už být náběh oblouku spektra dobře patrný.

12 K délkovým korekcím blíže viz např. SYROVÝ, V. Hudebni akustika. s. 245-246.

13 Literatury $\mathrm{k}$ tomuto tématu existuje množství, které by vydalo na samostatnou rešerši. Dobrým dokladem zmapování a popularity tématu je článek otisknutý v prestižním magazínu Science: CHEN, Jer Min, John SMITH a Joe WOLFE. Experienced saxophonists learn to tune their vocal tracts. Science. 2008, 319 (726).

14 Viz FLETCHER, N. a T. ROSSING. The Physics of Musical Instruments, s. 374.

15 Tato vlastnost souvisí s chováním hráčových rtů, které je analogické tlakově řízenému ventilu. Nejlepších výsledků dosahuje tehdy, může-li reagovat na velký odpor nástroje. Tuto vlastnost je ovšem potřeba neplést se subjektivním odporem, resp. snadností zahájení tónu, kterou hráč pocituje.

16 Viz např. Kolektiv autorů IWK. Akustik und Blechblasinstrumentenbau: Unterlagen zum Seminar, s. 72.

17 Viz FLETCHER, N. a T. ROSSING. The Physics of Musical Instruments, s. 387. 
Velké množství vy̌ších harmonických frekvencí, které je pro žestě, zejména ve větších dynamikách, typické, se ovšem nedá vysvětlit pouze filtrováním a zesilováním retného tónu. Pro pochopení tohoto fenoménu je nutná krátká odbočka.

Základní předpoklad, ze kterého vychází jednoduché akustické modely (tzv. lineární akustika), je, že tlakové změny vyvolané akustickým polem jsou oproti hodnotám atmosferického tlaku nesmírně malé. Ekvivalentně, že rychlost kmitání částeček vzduchu při průchodu zvuku je velmi malá. Pro signály dopadající při poslechu hudby na naše uši je tento předpoklad velmi dobře splněn. Pro představu, při hlasitosti $94 \mathrm{~dB}$, která už odpovídá znělému forte, je efektivní hodnota akustického tlaku 1 pascal (jedna stotisícina atmosféry) a odpovídající akustická rychlost zhruba tři milimetry za sekundu (devět metrů za hodinu - rychlost zvuku je více než stotisíckrát větší).

Musíme ale vzít $\mathrm{v}$ úvahu, že většina energie zůstane v rezonátoru nástroje: $\mathrm{v}$ běžné vzdálenosti pro hudební poslech jí zachytíme jen velmi malou část. Uvnitř nástroje byly, zejména ve zúžených profilech za kotlíkem nátrubku, naměřeny akustické tlaky přesahující $160 \mathrm{~dB}$, tedy hodnoty vysoko nad hmatovým prahem i prahem bolestivosti. Akustická rychlost kmitající částice pak už představuje řádově procenta rychlosti zvuku a není zanedbatelně malá (tzv. nelineární akustika ${ }^{18}$ ). Vlivem skládání rychlosti zvuku a akustické rychlosti pak dochází $\mathrm{k}$ nárůstu strmosti profilu vlny (wave steepening), který se projeví zvýšením počtu harmonických. Tato nelineární distorze může (i v hudebně významných př́padech) vést až ke vzniku rázové vlny (shock wave).

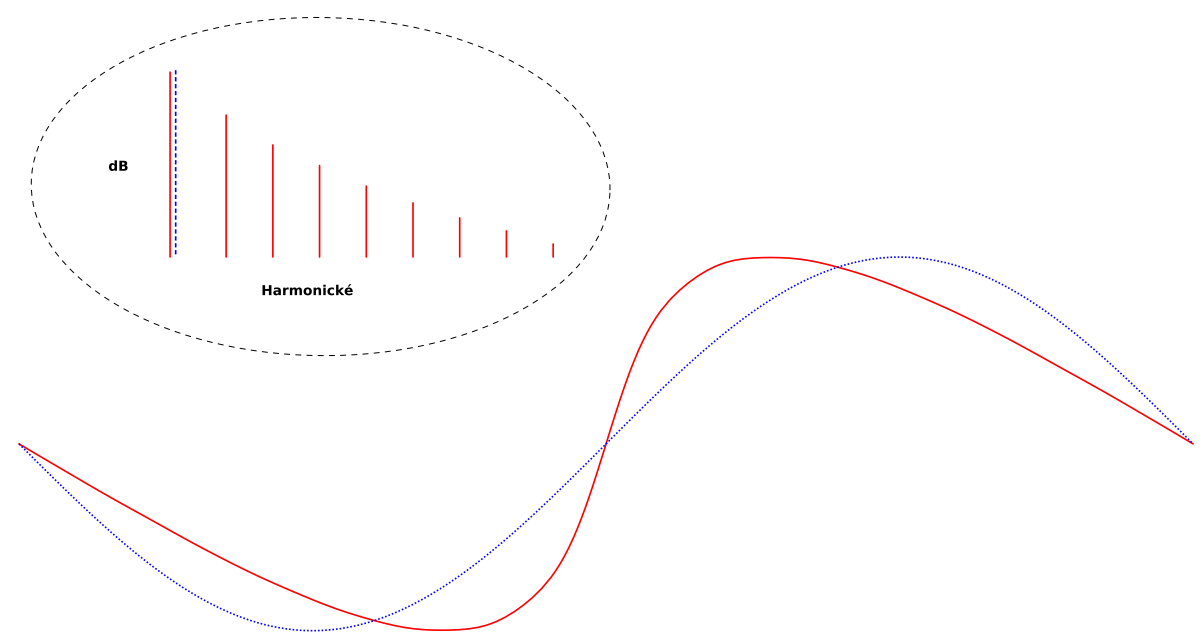

Obr. 3 Modelový príklad distorze původně sinusové vlny (modrá tečkovaná). Nahoře vlevo kvalitativní změna tvaru spektra.

18 Exaktnější definice tohoto pojmu vyžaduje matematický formalismus. Nejjednodušší platná definice totiž zní, že nelineární jsou ty systémy, které jsou popsány nelineárními rovnicemi. Jejich typickými vlastnostmi je zejména ztráta principu superpozice (nemusí platit, že „1+ $1=2 “$ ) a zvýšení složitosti vnitřních závislostí v systému (vlastnosti oscilátoru závisí na vlastnostech rezonátoru apod.). To má za následek (kromě mnoha dalších fenoménů), že zvukový výstup z nástroje se nedá získat jako jednoduchá transformace zvukového vstupu. Viz o tom dále. 
Jen pro úplnost, nelineárně se chová i oscilátor v podobě kmitajících rtů. Pomocí zpětné vazby rezonátor-oscilátor se rty opírají nejen o impedanci frekvence základního tónu, ale svými vy̌šsími harmonickými i o další vrcholy vstupní impedance. Pokud ty tedy nejsou harmonicky seřazeny, opora se ztrácí a subjektivní snadnost zahájení tónu se zhorší. Na druhé straně, právě opora v dalších impedančních maximech umožňuje intonovat pedálové tóny hlubších válcových žestủ přesně. Rezonanční frekvence u těchto nástrojů bývají seřazeny zhruba podle posloupnosti $0,7: 2: 3: 4$ atd, tzn. interval mezi první a druhou vlastní frekvencí je bezmála duodecima a hráč se opírá o interakce s druhou a vyššími vlastními frekvencemi. ${ }^{19}$

\section{Praktická měření a organologická systematika}

Ponecháme stranou nejrůznější experimentální sestavy, které slouží k čistě akustickému výzkumu a budeme se soustředit pouze na některé organologicky významné úlohy a z nich navíc jen na ty, které vylučují vliv hráče a nevyžadují hlubší znalosti fyzikální akustiky.

Zjištění ladění a hratelných tónů nástroje lze s velmi dobrou přesností provést měřením vstupní impedance nástroje (maxima vstupní impedance odpovídají tónům, které nástroj může vyloudit). V současné době asi nejúspěšnější nástroj sloužící k tomuto měření je komerčně dostupná sestava hardware a software BIAS (Brass Instrument Analysis System), kterou dlouhodobě vyvijí rakouský Institut für Wiener Klangstil. ${ }^{20}$ Zařízení určuje vstupní impedanci z odezvy nástroje na sinusový sweep. Kromě přirozených tónů nástroje lze po jisté zkušenosti z rozložení vstupní impedance odhadnout i snadnost zahájení tónu a obtí̌nost vazby při přechodu mezi alikvóty. ${ }^{21}$

Pokud není př́ślušný systém $\mathrm{k}$ dispozici nebo je nástroj poškozen natolik, že není schopen spolehlivé hry - a tedy ani spolehlivého akustického testu - lze dobrou představu získat i pomocí měření geometrie nástroje běžnými prostředky (,provázkem a šuplérou“). Nejčastěji je potřeba zjistit vývoj vnitřního průměru nástroje v závislosti na vzdálenosti od nátrubku. Tyto údaje lze použít k výpočtu vstupní impedance modelováním přenosových vlastností nástroje..$^{22}$ Není nutné, aby organolog znal detaily výpočtu, lze ho poměrně snadno algoritmizovat tak, aby do jednoduchého softwaru stačilo zadat geometrické údaje. Tuto možnost nabízí např́íklad skript Brass Earwig vyvinutý autorem tohoto

19 Viz FLETCHER, N. a T. ROSSING. The Physics of Musical Instruments, s. 369.

20 Více o systému viz web BIAS. Artim [online]. Gänserndorf: Acoustic Rating Technology for Instrument Makers GmbH [cit. 2016-09-20]. Dostupné z: http://www.bias.at/.

21 Jednoduše srozumitelnou kapitolu obsahuje německé skriptum: Kolektiv autorů IWK. Akustik und Blechblasinstrumentenbau: Unterlagen zum Seminar, s. 60nn.

22 Literatury opět existuje větší množství. Obvykle jako základní bývá citován článek MAPES-RIORDAN, Dan. Horn Modeling with Conical and Cylindrical Transmission-Line Elements. Journal of Audio Engineering Society. 1993, 41(6), s. 471-484. 
článku ve Výzkumném centru hudebni akustiky $A M U$. Se stejnými vstupními údaji pracují i pokročilejší postupy modelující šíření většího množství frekvencí trubicí nástroje. ${ }^{23}$

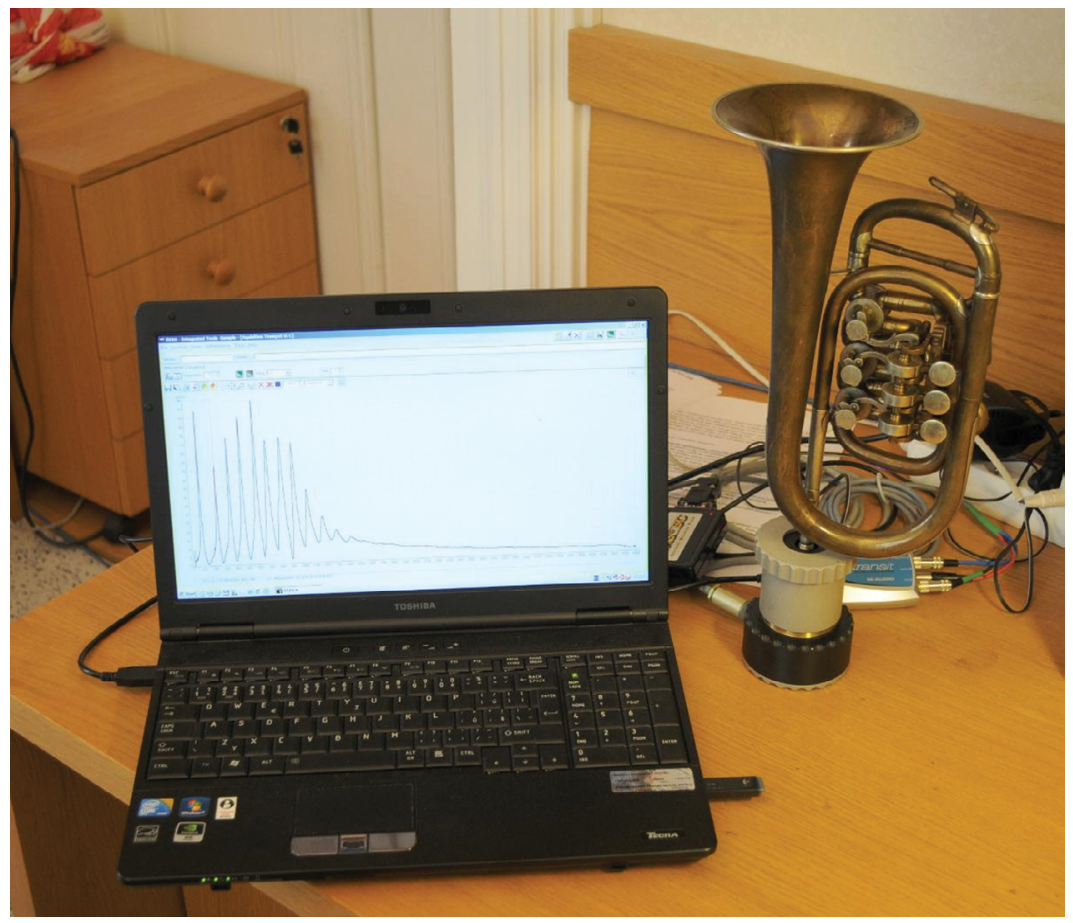

Obr. 4 Šedivův světový kornet (všemirnyj kornet) v hlavě měříciho systému BIAS. Na obrazovce tvar křivky vstupní impedance z konkrétního měření. Foto: Jan Kříženecký, České muzeum hudby.

Konečně také máme $\mathrm{k}$ dispozici dost základních informací, abychom se mohli věnovat organologické systematice. Systém Sachs-Hornbostel ${ }^{24}$ zohledňuje profil trubice nástroje až na nízké taxonomické úrovni. Máme-li na zřeteli vývoj nástrojů z řemeslného a etnologického hlediska, pak jsou např. existence samostatného nátrubku nebo zařízení strojiva a snižce nepochybně na důležitější pozici. Přesto má smysl pokusit se o klasifikaci na základě vlastností trubice samotné. Jednak se precizují poněkud chromé formulace „nástroj kónický“, „nástroj cylindrický“ a kromě toho bude možné hledat společné a rozdílné znaky u nástrojů napříč sachs-hornbostelovskými oddíly.

23 KEMP, Jonathan K. Theoretical and experimental study of wave propagation in brass musical instruments. Edinburgh, 2002. Dizertace.

24 Konsorcium MIMO (Musical Instruments Museums Online) vydalo rozšíření taxonomie Sachs-Hornbostel, které rozlišuje ještě délku vzdušného sloupce a šiřku trubice. Samozřejmě, bez narušení původního schématu, tzn. taxonomická úroveň se nemění. Mimochodem, zde se důsledně užívá označení labrosony. (MIMO, Musical Instruments Museums Online. Revision of the Hornbostel-Sachs Classification of Musical Instruments by the MIMO Consortium [online]. 2011 [cit. 2016-09-20]. Dostupné z: http://www.mimo-international.com/documents/ Hornbostel\%20Sachs.pdf.) 
Velmi zajímavou práci na tomto poli v posledních letech odvedla skupina soustředěná kolem Arnolda Myerse a Donalda Murrayho Campbella (další viz literatura). ${ }^{25}$ Jejich taxonomie staví na už zmíněném jevu nelineární distorze vlny, který charakteristicky dělí „válcové“ a „kuželové“ nástroje. Zavádí nový parametr potenciál břesknosti $B$ (orig. brassiness potential) odpovídající schopnosti nástroje vydat typický břeskný (brassy) tón. Všimněme si opatrného použití slova „potenciál“. Je více než namístě. Sám hráč totiž přizpůsobením svého nátisku může břesknost tónu výrazně ovlivnit, často velmi nevkusně. Parametr $B$ má ovšem vypovídat o tom, jak moc to nástroj, na hráči nezávisle, umožňuje.

Lze najít délku dokonale válcové trubice, která bude mít stejnou míru nelineární distorze jako měřený hudební nástroj. $\mathrm{V}$ drtivé většině případů je délka takového válce menší než reálná délka nástroje, protože rozprostírání vlnoplochy po rozšiřujícím se průřezu tlumí nelineární jevy spojené s vysokými intenzitami zvuku. Potenciál břesknosti je pak zaveden jako poměr délky tohoto ekvivalentního válce $\mathrm{k}$ délce takového kužele (včetně doplňku), který má stejnou základní frekvenci jako měřený hudební nástroj. Prakticky lze potenciál břesknosti určit pouhým geometrickým měřením nástroje. Potřebné vzorce jsou v apendixu článku, jejich matematický aparát je jednoduchý.

Významná vlastnost potenciálu břesknosti je ta, že se nemění při celkové změně měřítek trubice, takže např́k lad trubka in $\mathrm{B}$ a in $\mathrm{C}$ vychází prakticky shodně. Ukázalo se nicméně, že samotný potenciál břesknosti jako jediný ukazatel nepodává úplnou potřebnou informaci (např. lesní roh a baryton by spadaly do stejné kategorie, $B$ zhruba 0,5 ). Spolu s ním je vhodné uvádět vstupní průměr nástroje, protože ten ovlivňuje množství akustického tlaku, který hráč musí do nástroje vpustit, aby dosáhl požadované dynamiky. ${ }^{26}$

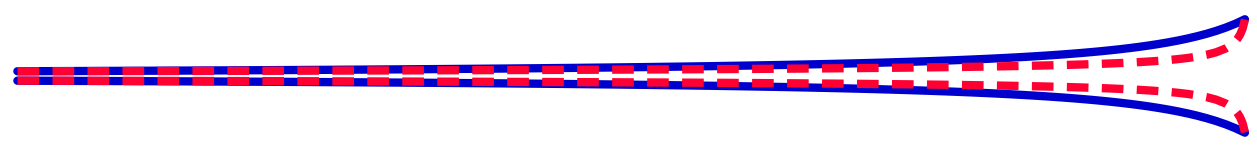

Obr. 5 llustrační srovnání dvou profilů trubic, které se neliší délkou, vstupním ani výstupním průměrem, ale pouze mírou postupného rozšiirování. Potenciál břesknosti modré je 0,58 , červené 0,65 . Nad profily je vyznačena délka válce o shodné miře nelineární distorze. Pro užší (červený) profil je ekvivalentní válec delší.

25 MYERS, Arnold, Robert W. PYLE, Joël GILBERT, D. Murray CAMPBELL, John P. CHICK a Shona LOGIE. Effects of nonlinear sound propagation on the characteristic timbres of brass instruments. Journal of Acoustical Society of America. 2012, 131(1), s. 678-688.

26 Tamtéž. 


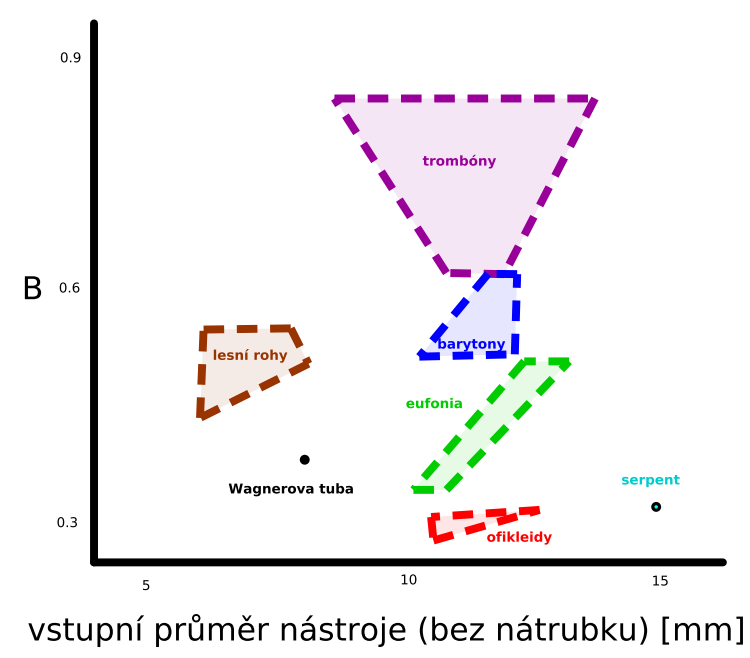

Obr. 6 Ilustrační příklad použití taxonomického schématu potenciál břesknosti - vstupní průměr. ${ }^{27}$ Získané schéma je postaveno na konkrétních experimentálních datech. Neznamená tedy, že neexistují nástroje $v$ přechodových verzích mezi oblastmi. Pouze žádné takové nebyly testovány $\mathrm{v}$ rámci studie.

Máme tedy dvoudimenzionální taxonomické schéma. Dosavadní výzkumy ukazují, že jednotlivé druhy nátrubkových nástrojů tvoří v rámci taxonomické roviny poměrně jasně oddělené oblasti. V rámci oblastí je ale možné odlišit jednotlivé modely nebo nástrojařské školy. ${ }^{28}$ Šedivovy nástroje s distribučním ventilem, který umožňuje změnit profil trubice nástroje při zachování stejného ladění (šedifony), vlastně existují v taxonomickém schématu jako dva body př́imo nad sebou (vstupní průměr se nemění, potenciál břesknosti ano). ${ }^{29}$ Altový šedifon má při vstupním průměru $13 \mathrm{~mm}$ potenciály břesknosti 0,46 a 0,76 . $\mathrm{Z}$ obr. 6 vidíme, že jeden profil tedy skutečně kvalitativně odpovídá trombónu a druhý eufoniu.

\section{Poznámka o modelování zvuku}

Široce diskutované téma možnosti syntézy zvuku nátrubkových nástrojů vybočuje ze zaměření této studie. $\mathrm{S}$ vybudovanou teorií je nicméně užitečné aspoň pro přehled několik poznámek bez širšího kontextu udělat.

27 Podle MYERS, Arnold, Robert PYLE, Joël GILBERT a Murray CAMPBELL. The Influence of the bore size on brassiness potential. In Proceedings of the 2nd Vienna Talk. Vídeň: University of Performing Arts in Vienna, 2010, s. 102-105.

28 Tamtéž.

29 ŽƯRKOVÁ, František IBL a Jakub KLIMEŠ. Duplex Brass Instruments of Josef Šediva and their Functionality Analysed by Finite Amplitude Sound Propagation Theory. Akustika. 2017, 28(1), s. 44-49. 
Jednoduchá lineární teorie filtrů by mohla pracovat s modelovým signálem „tónu“ hráčových rtů, jehož spektrum by bylo tvarováno vlastnostmi nástroje a parametry vyzařování. Takto získaný zvuk je však při poslechu velmi nedůvěryhodný. Problém je především v chybějícím modelu zahájení tónu, který je ovšem pro vjem barvy klíčový. Dále je nutné zohlednit zpětnou vazbu rezonátor-oscilátor, která významně ovlivňuje tvar vstupního signálu ze rtů. Významný je rovněž fenomén obohacení spektra o nové harmonické kvůli nelineární distorzi. Lineární teorie filtrace neumí vysvětlit zrod nových harmonických během vedení zvuku v trubici.

Klasická práce se zvukem ve spektrální doméně tedy nestačí, je potřeba programovat modely v časové doméně. Relativně dobře znějící syntézy jsou dnes pořizovány pomocí nelineárního modelování. To je však poměrně náročné, na obecně přijímané univerzálnější algoritmy si ještě musíme počkat a výpočetní čas je i při možnostech dnešních procesorů př́liš vysoký na to, aby bylo možné „snadno a rychle naprogramovat a provést koncert".

\section{Závěr}

Výběr témat pro tuto studii se řídil hlavní linkou, která vedla od přirozených tónů nátrubkového nástroje s ohledem na jeho profil k organologické systematice založené na potenciálu břesknosti. Je tedy namístě alespoň ve výčtu zmínit některá důležitá témata, která text poněkud obešel.

Především je to vliv nátrubku. Ospravedlnění tohoto postupu je stejné, které v citované studii uvádí Arnold Myers a kol.: nátrubek je proměnná část systému, hráč si podle osobních preferencí volí ze širokého spektra druhů i v rámci uplatnění na jednom konkrétním typu nástroje. Z hlediska organologické systematiky je tedy výhodné jeho vliv vyloučit. Definice potenciálu břesknosti (viz apendix) bere v potaz až vstupní průměr v ústnici nástroje za nátrubkem. Zahrnout nátrubek je ovšem bezpodmínečně nutné, pokud určujeme vlastnosti nástroje ze vstupní impedance.

Stejně tak nebyla blíže vykládána mechanika buzení tónu hráčovými rty. Existuje přístup popisující akustické vlastnosti nátrubkového nástroje (labrosonu) z vlastností geometrické křivosti rozšiřování trubice. ${ }^{30} \mathrm{~V}$ této studii byl nicméně záměrně opomenut $\mathrm{z}$ důvodů rozsahu, čitelnosti a jednoduchosti aplikace.

Hudební akustika včetně příslušného fyzikálního modelování se čím dál více stává běžnou součástí nejen systematické, ale i historické organologie. Vzhledem k vývoji světové organologické literatury by bylo dobré, aby i v češtině textů pohybujících se na tomto pomezí spíše přibývalo.

30 Viz např. BENADE, Arthur H. a Erik V. JANSSON. On Plane and Spherical Waves in Horns with Nonuniform Flare: I. Theory of Radiation, Resonance Frequencies. Acustica. 1974, 31(2), s. 80-98. 


\section{Apendix}

\section{Vzorce pro prirozené tóny trubic}

Frekvence přirozených tónů válcové trubice na jednom konci dokonale uzavřené a na druhém dokonale otevřené, bez uvažování ztrát třením, lze získat ze vzorce:

$$
f_{n}=\frac{c}{4 L}(2 n-1)
$$

kde $c$ je rychlost zvuku, ${ }^{31} L$ délka trubice a $n$ přirozené číslo (tzn. $1,2,3, \ldots$ ).

Pro kuželovou trubici máme přibližný vzorec:

$f_{n}=\frac{n c}{2 L}\left(1-\frac{x_{0}}{L}\right)$

kde $x_{0}$ je délka kuželového doplňku. Tento vzorec ovšem platí pouze pro velmi malé kuželové doplňky. Přesný vztah vyžaduje řešení rovnice:

$$
k L=n \pi-\operatorname{arctg} k x_{0}, \quad k=\frac{2 \pi f}{c}
$$

kde $k$ je vlnové číslo zavedené druhým ze vztahů. Tato rovnice tzv. transcendentního typu nemá analytické řešení (tzn. není možné z ní vyjádřit frekvenci, zbývají pouze numerická řešení).

Frekvence přirozených tónů Besselova vlnovodu odpovídají následujícímu vzorci:

$$
f_{n}=\frac{c}{4\left(L+x_{0}\right)}[2 n-1+\beta \sqrt{\gamma(\gamma+1)}]
$$

kde $\gamma, x_{0}$ jsou parametry geometrie trubice (viz níže) a $\beta$ je 0,6 pro $\gamma\langle 0,8$ a 0,7 pro $\gamma>$ 0,8 . Podstatné je, že pro $\gamma=1$ (což by odpovídalo kónickým žest̉ům), ze vzorce vyplývá:

$$
f_{n} \approx \frac{n c}{2\left(L+x_{0}\right)}
$$

tzn. případ, kdy jsou frekvence všech přirozených tónů v harmonických poměrech.

\section{Geometrie Besselova vlnovodu}

Besselův vlnovod je taková trubice, pro jejíž vnitřní poloměr $r$ platí:

$$
r=\frac{b}{\left(x+x_{0}\right)^{\gamma}}
$$

kde $b$ a $x_{0}$ jsou konstanty, které je potřeba určit z počátečního a konečného průměru trubice. Parametr $\gamma$ nabývá hodnot blízkých 1. Čím menší, tím déle je profil trubice úzký a finální rozšíření prudší.

31 V dechem zahřátých trubicích je namístě brát hodnotu mezi 340 a 350 metry za sekundu. 
$\mathrm{V}$ podstatě se jedná o zobecněnou hyperbolu, ze které je parametrem $x_{0}$ odňat konec rostoucí nade všechny meze. Besselovy vlnovody podle výše uvedeného předpisu jsou orientovány tak, že hráč schématicky hraje zprava doleva. To je ovšem pouze záležitost grafické reprezentace.

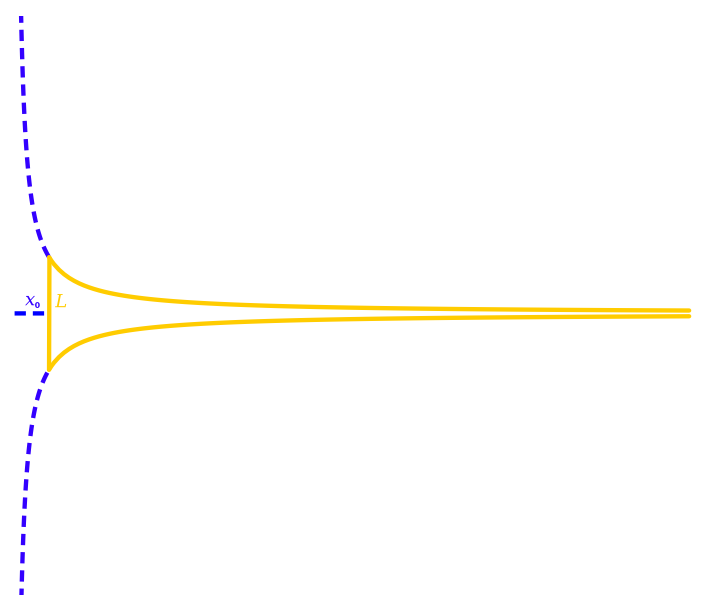

Obr. 7 Besselův vlnovod $s$ vyznačeným doplňkem $x_{0}$ jako vzdáleností, ve které by se stěny vinovodu rozrostly nade všechny meze.

\section{Vzorec pro potenciál břesknosti a postup měreni}

Rodělíme délku nástroje na $N$ dílů tak, abychom dobře pokryli rozšiřující se profil (tzn. stačí jen málo údajů pro $\mathrm{v}$ podstatě válcové části a naopak je potřeba měření zjemnit v prudce se rozšiřujících částech). Označíme $l_{n}$ délku $n$-tého dílu nástroje a $D_{n}$ průměr jeho vstupu. $D_{0}$ je průměr ústnice v místě, kde končí při zasunutí stopka nátrubku. Potenciál břesknosti $B$ pak určíme podle vzorce:

$B \approx \frac{1}{L_{\mathrm{ecl}}} \sum_{n=1}^{N} l_{n} \frac{2 D_{0}}{D_{n-1}+D_{n}} \equiv \frac{1}{L_{\mathrm{ecl}}}\left(l_{1} \frac{2 D_{0}}{D_{0}+D_{1}}+l_{2} \frac{2 D_{0}}{D_{1}+D_{2}}+\ldots\right)$

kde $L_{e c l}$ je délka kužele (včetně doplňku), který má stejný základní tón jako měřený profil (zkratka ecl je z anglického equivalent cone length). Příslušný vzorec se nachází výše.

Tato studie vznikla na Akademii múzických umění v Praze v rámci projektu Zvuková kvalita podpořeného z prostředků Institucionální podpory na dlouhodobý koncepční rozvoj výzkumné organizace, kterou poskytlo MŠMT v roce 2016. 


\section{Bibliography}

BIAS. Artim [online]. Gänserndorf: Acoustic Rating Technology for Instrument Makers GmbH [cit. 2016-09-20]. Dostupné z: http://www.bias.at/

BENADE, Arthur H. a Erik V. JANSSON. On Plane and Spherical Waves in Horns with Nonuniform Flare: I. Theory of Radiation, Resonance Frequencies. Acustica. 1974, 31(2), 80-98.

CHEN, Jer Min, John SMITH a Joe WOLFE. Experienced saxophonists learn to tune their vocal tracts. Science. 2008, 319 (726).

FLETCHER, Neville H. a Thomas D. ROSSING. The Physics of Musical Instruments. 2nd ed. New York: Springer, 2010. ISBN 978-144-1931-207.

HORNBOSTEL, Erich Moritz von a Curt SACHS. Systematik der Musikinstrumente: Ein Versuch. Zeitschrift für Ethnologie. 1914, (4-5), s. 553-590.

HRUŠKA, Viktor, Tereza ŽŮRKOVÁ, František IBL a Jakub KLIMEŠ. Duplex Brass Instruments of Josef Šediva and their Functionality Analysed by Finite Amplitude Sound Propagation Theory. Akustika. 2017, 28(1), s. 44-49.

IRMANN, Karel, Josef PRACH, Jiří ŠVAGR, Vratislav VIMR a Stanislav PAVÍLEK. Stavba hudebnich nástrojů. Praha: Státní pedagogické nakladatelství, 1968.

KEMP, Jonathan K. Theoretical and experimental study of wave propagation in brass musical instruments. Edinburgh, 2002. Dizertace.

Kolektiv autorů IWK (Institut für wiener Klangstil). Akustik und Blechblasinstrumentenbau: Unterlagen zum Seminar. Vídeň: Universität für Musik und darstellende Kunst Wien, 2004.

KURFÜRST, Pavel. Organologie: (propedeutika, exemplifikace). Hradec Králové: Georgius, 1998. ISBN 80-902-5480-2.

MAPES-RIORDAN, Dan. Horn Modeling with Conical and Cylindrical Transmission-Line Elements. Journal of Audio Engineering Society. 1993, 41(6), s. 471-484.

MIMO, Musical Instruments Museums Online. Revision of the Hornbostel-Sachs Classification of Musical Instruments by the MIMO Consortium [online]. 2011 [cit. 2016-09-20]. Dostupné z: http:// www.mimo-international.com/documents/Hornbostel\%20Sachs.pdf.

MYERS, Arnold, Robert W. PYLE, Joël GILBERT, D. Murray CAMPBELL, John P. CHICK a Shona LOGIE. Effects of nonlinear sound propagation on the characteristic timbres of brass instruments. Journal of Acoustical Society of America. 2012, 131(1), s. 678-688.

MYERS, Arnold, Robert PYLE, Joël GILBERT a Murray CAMPBELL. The Influence of the bore size on brassiness potential. In: Proceedings of the 2nd Vienna Talk. Vídeň: University of Performing Arts in Vienna, 2010, s. 102-105.

RYCHLÍK, Jan. Žestové nástroje bez strojiva. Praha: SNKLHU, 1960.

SYROVÝ, Václav. Hudebni akustika. 2., dopl. vyd. V Praze: Akademie múzických umění, 2008. Akustická knihovna Zvukového studia Hudební fakulty AMU. ISBN 978-80-7331-127-8.

ŠPELDA, Antonín. Hudebni akustika: pro posluchače filosofických a pedagogických fakult a akademii múzických uměni. Praha: Státní pedagogické nakladatelství, 1978.

UŠÁK, Jaroslav. Pokus o nové roztř́íění hudebních nástrojů. Hudebni rozhledy. 1927, (2).

ŽU゚RKOVÁ, Tereza a Viktor HRUŠKA. Josef Šediva (1853-1915) a jeho sbirka hudebních nástrojů v Národním muzeu - Českém muzeu hudby. Praha: Národní muzeum, 2016. Editio Monographica Musei Nationalis Pragae. ISBN 978-80-7036-505-2. 